\title{
Chemical Composition and Larvicidal Activity of Essential Oils Extracted from Brazilian Legal Amazon Plants against Aedes aegypti L. (Diptera: Culicidae)
}

\author{
Clarice Noleto Dias, ${ }^{1}$ Luciana Patrícia Lima Alves, ${ }^{1}$ Klinger Antonio da Franca Rodrigues, ${ }^{2}$ \\ Maria Cristiane Aranha Brito, ${ }^{2}$ Carliane dos Santos Rosa, ${ }^{2}$ \\ Flavia Maria Mendonça do Amaral, ${ }^{2}$ Odair dos Santos Monteiro, ${ }^{3}$ \\ Eloisa Helena de Aguiar Andrade, ${ }^{4}$ José Guilherme Soares Maia, \\ and Denise Fernandes Coutinho Moraes ${ }^{1,2}$

\footnotetext{
${ }^{1}$ Programa de Pós-Graduação em Saúde e Ambiente, Universidade Federal do Maranhão, 65085-580 São Luís, MA, Brazil

${ }^{2}$ Departamento de Farmácia, Universidade Federal do Maranhão, 65085-580 São Luís, MA, Brazil

${ }^{3}$ Programa de Pós-Graduação em Química, Universidade Federal do Maranhão, 65085-580 São Luís, MA, Brazil

${ }^{4}$ Programa de Pós-Graduação em Química, Universidade Federal do Pará, 66075-900 Belém, PA, Brazil

${ }^{5}$ Programa de Pós-Graduação em Recursos Naturais da Amazônia, Universidade Federal do Oeste do Pará,
} \\ 68035-110 Santarém, PA, Brazil
}

Correspondence should be addressed to Clarice Noleto Dias; cla_noleto@yahoo.com.br

Received 15 February 2015; Revised 20 March 2015; Accepted 21 March 2015

Academic Editor: Vincenzo De Feo

Copyright (C) 2015 Clarice Noleto Dias et al. This is an open access article distributed under the Creative Commons Attribution License, which permits unrestricted use, distribution, and reproduction in any medium, provided the original work is properly cited.

\begin{abstract}
The mosquito Aedes aegypti L. (Diptera: Culicidae) is the major vector of dengue and chikungunya fever. The lack of effective therapies and vaccines for these diseases highlights the need for alternative strategies to control the spread of virus. Therefore, this study investigated the larvicidal potential of essential oils from common plant species obtained from the Chapada das Mesas National Park, Brazil, against third instar A. aegypti larvae. The chemical composition of these oils was determined by gas chromatography coupled to mass spectrometry. The essential oils of Eugenia piauhiensis Vellaff., Myrcia erythroxylon O. Berg, Psidium myrsinites DC., and Siparuna camporum (Tul.) A. DC. were observed to be mainly composed of sesquiterpene hydrocarbons. The essential oil of Lippia gracilis Schauer was composed of oxygenated monoterpenes. Four of the five tested oils were effective against the $A$. aegypti larvae, with the lethal concentration $\left(\mathrm{LC}_{50}\right)$ ranging from 230 to $292 \mathrm{mg} / \mathrm{L}$ after $24 \mathrm{~h}$ of exposure. Overall, this work demonstrated the possibility of developing larvicidal products against $A$. aegypti by using essential oils from the flora of the Brazilian Legal Amazon. This in turn demonstrates the potential of using natural resources for the control of disease vectors.
\end{abstract}

\section{Introduction}

The Brazilian Legal Amazon encompasses approximately 5 million square kilometers. This area is going through a serious deforestation process and the state of Maranhão has one of the highest rates $[1,2]$. An important step towards protecting its biodiversity was the creation of the Chapada das Mesas National Park, located in the central-southern region of the state [3].
Another important way towards the preservation of biodiversity is the search for plant products that could be used in order to provide a sustainable development of the Amazon [4]. Although several research groups have been devoted to the study of phytotherapeutic agents, phytocosmetics, and medicinal plants in this region, Frickmann and Vasconcellos [5] have reported that the research conducted has not contributed to the development of many innovative products so far. 
TABLE 1: Plant species collected from the Chapada das Mesas National Park, central-southern region of the state of Maranhão, Brazil.

\begin{tabular}{|c|c|c|c|}
\hline Family and plant species & $\begin{array}{c}\text { Geographical } \\
\text { coordinates }\end{array}$ & Dates & Records of collections \\
\hline \multicolumn{4}{|l|}{ Myrtaceae } \\
\hline Eugenia piauhiensis Vellaff. & $\begin{array}{l}07^{\circ} 19^{\prime} 14.8^{\prime \prime} \mathrm{S} \\
47^{\circ} 19^{\prime} 14.8^{\prime \prime} \mathrm{W}\end{array}$ & $02 / 28 / 2012$ & L-3146 \\
\hline Myrcia erythroxylon O. Berg & $\begin{array}{l}07^{\circ} 09^{\prime} 32.7^{\prime \prime} \mathrm{S} \\
47^{\circ} 24^{\prime} 05.1^{\prime \prime} \mathrm{W}\end{array}$ & 07/20/2011 & L-2907 \\
\hline Psidium myrsinites DC. & $\begin{array}{l}07^{\circ} 06^{\prime} 3.65^{\prime \prime} \mathrm{S} ; \\
47^{\circ} 20^{\prime} 35.3^{\prime \prime} \mathrm{W}\end{array}$ & $02 / 28 / 2012$ & $\mathrm{~L}-3152$ \\
\hline \multicolumn{4}{|l|}{ Siparunaceae } \\
\hline Siparuna camporum (Tul.) A. DC. & $\begin{array}{l}07^{\circ} 03^{\prime} 04.6^{\prime \prime} \mathrm{S} \\
47^{\circ} 27^{\prime} 09.1^{\prime \prime} \mathrm{W}\end{array}$ & $03 / 01 / 2012$ & $\mathrm{~L}-3174$ \\
\hline \multicolumn{4}{|l|}{ Verbenaceae } \\
\hline Lippia gracilis Schauer & $\begin{array}{l}07^{\circ} 06^{\prime} 3.65^{\prime \prime} \mathrm{S} ; \\
47^{\circ} 20^{\prime} 35.3^{\prime \prime} \mathrm{W}\end{array}$ & $02 / 28 / 2012$ & L-3151 \\
\hline
\end{tabular}

The use of essential oils as insecticides is a highly promising initiative to develop and preserve the region [6-8]. They are known to be complex mixtures of secondary metabolites that can be obtained at low costs using renewable technology, often displaying higher activities than the individual isolated compounds [9].

Some acute virus diseases, such as dengue and chikungunya fever, are transmitted through the bite of female Aedes (Stegomyia) aegypti L. (1762) (Diptera: Culicidae) mosquitoes $[10,11]$. Dengue fever has been classified as the most important disease caused by arbovirus in the world [12]. Chikungunya fever has seen unprecedented global expansion during 2004, with epidemics recorded in Africa, Asia, and the islands of the Indian Ocean and in areas with temperate climate, such as Europe [13], and has been overspread quickly in Brazil, where there were 1,750 reported cases of this illness in 2014 [14]. Despite extensive research, these diseases currently have no treatment or any officially approved vaccine [15].

Preventing the spread of these viruses is, consequently, dependent on the eradication of their main vector, the arthropod A. aegypti [16]. Chemical control, through the use of insecticides, is the approach most commonly employed by public health initiatives [17]. Focal treatment, which involves the eradication of immature forms of A. aegypti by using larvicides (such as the organophosphate temefos) in the specific places where the larvae can be found, is a very efficient approach $[18,19]$. However, the regular and repeated use of these insecticides has resulted in the development of resistant strains [20].

Although some previous studies have been performed with the aim to evaluate the larvicidal activity of essential oils, in general, these studies are not conducted with the ultimate goal of producing plant-based larvicides [9]. This study is focused on the sustainable use of Amazonian aromatic plants and the development of new products to combat the spread of the dengue and chikungunya virus. The main aim of this study was to test the larvicidal activity against $A$. aegypti of essential oils from five common plant species found in the Brazilian Legal Amazon, plants that have been poorly studied so far, as well as to determine the chemical composition of these oils, in order to establish the quality parameters of the bioproducts.

\section{Materials and Methods}

2.1. Plant Material. The collection of aromatic plants was based on conformance to standard sensorial criteria and the observation of morphological traits; the inspections were performed by collaborating botanists present during sample collection to determine if a particular sample belonged to one of the families of aromatic plants. The inclusion criteria favored the inclusion of poorly researched plant species.

Leaves were collected from adult specimens of the selected plants in the early morning. The plants were endemic to several regions within the Chapada das Mesas National Park, Maranhão, Brazil, as well as several buffer zones of the Park. This area was a constituent of the Unit of Environmental Conservation and included Amazonian plants and plants found in the Cerrado region of the state of Maranhão. The permission for plants collection (process number: 28007-2) was provided by the System of Authorization and Information in Biodiversity of the Chico Mendes Institute of Conservation and Biodiversity (Instituto Chico Mendes de Conservação da Biodiversidade (ICMBio)), Ministry of Environment, Brazil.

The species identification was performed at the Herbarium João Murça Pires of the Emílio Goeldi Pará Museum, Belém, Pará, Brazil. The complete list of collected species and the geographical coordinates, dates, and records of collections are provided in Table 1.

2.2. Plant Processing and Extraction of the Essential Oils. The leaves of collected plants were air-dried, ground, and submitted to hydrodistillation, using a Clevenger-type apparatus (100 g each, $3 \mathrm{~h}$ ). The oils were dried over anhydrous sodium sulfate. The percentage content of oil was calculated based on plant dry weight. 
2.3. Essential Oils-Composition Analyses. The analyses of the oils were carried out on a THERMO DSQ II GC-MS instrument (Thermo Fisher Scientific, Austin, TX, USA), under the same conditions previously described [23].

Individual components were identified by comparison of both mass spectrum and GC retention data with authentic compounds, which were previously analyzed and stored in a private library [21], as well as with the aid of commercial libraries containing retention indices and mass spectra of volatile compounds commonly found in essential oils [22, 24].

2.4. Larvicidal Activity Assay. A. aegypti eggs were collected using ovitraps [25] that were distributed in neighborhoods with high incidence of dengue in São Luís, Maranhão, Brazil. The pallets containing the eggs were submerged in dechlorinated tap water in order to allow hatching of the eggs; ground Purina Cat Chow $(0.3 \mathrm{~g})$ was added to the water to improve the conditions for larval development. Larvae were incubated in order to achieve the third instar stage, the optimal bioassay phase. Larvae were grown at controlled temperatures $\left(25 \pm 2^{\circ} \mathrm{C}\right)$ with a $12 \mathrm{~h}$ photoperiod. The larvae were identified using Consoli and Oliveira keys [26].

The larvicidal activity bioassay was performed according to the method proposed by the World Health Organization, with slight modifications [27]. The stock solutions of each essential oil sample were prepared in mineral water and $0.01 \%$ dimethyl sulfoxide (DMSO). Aliquots of the stock solutions were used to prepare solutions of six different concentrations (20 mL; 50, 100, 200, 300, 400, and $1000 \mathrm{mg} / \mathrm{L})$. Ten larvae were added to each solution. The mortality was scored $24 \mathrm{~h}$ after the start of the experiment. A $0.01 \%$ DMSO solution and a $1 \mathrm{mg} / \mathrm{L}$ temefos solution were used as the negative and positive control, respectively. Each assay was performed in triplicate (repeated three times on different days).

2.5. Statistical Analyses. The half-maximal lethal concentration $\left(\mathrm{LC}_{50}\right)$ value was calculated using probit regression model (SPSS program, version 13.0) and assuming a confidence level of $95 \%(P<0.05)$.

\section{Results and Discussion}

3.1. Analysis of the Essential Oil Composition. The essential oils were extracted from the leaves of Eugenia piauhiensis Vellaff., Myrcia erythroxylon O. Berg, Psidium myrsinites DC., Siparuna camporum (Tul.) A. DC., and Lippia gracilis Schauer at yields of $0.43,0.53,0.39,1.40$, and $7.99 \%(\mathrm{v} / \mathrm{w})$, respectively. The density of all extracted oils was less than that of water, while the oil color was light yellow. Fifty-six components, representing 91.94 to $99.64 \%$ of the oils, were identified (Table 2).

Sesquiterpene hydrocarbons were the major identified components in the oils of E. piauhiensis, M. erythroxylon, P. myrsinites, and S. camporum, whereas 1,8-cineole and $\alpha$ terpineol oxygenated monoterpenes were the major components observed in L. gracilis. The major components of $E$. piauhiensis, M. erythroxylon, P. myrsinites, and S. camporum were $\gamma$-elemene and $(E)$ - $\beta$-caryophyllene, germacrene $\mathrm{D}$ and bicyclogermacrene, $(E)-\beta$-caryophyllene and $\alpha$-humulene, and $\gamma$-patchoulene and $\alpha$-phellandrene, respectively.

The composition and yield of the essential oils of each plant species may vary according to the genetic, environmental, and physiopathological traits influencing the plant metabolism. The total quantity, as well as the relative proportions of secondary metabolites in plants, can be regulated by biotic and abiotic factors, such as the season, area, and time of collection of the samples [28-31]. This demonstrates the relevance of chemical and biochemical studies using plants collected from different regions, during different times of the year.

Maia et al. [32] revealed that $P$. myrsinites leaves, collected from Anapurus, in the Maranhão region of the Amazon, were mainly composed of $(E)$ - $\beta$-caryophyllene $(28.7 \%)$ and $\alpha$-humulene (19.4\%), which is in agreement with the results presented in this study. The similarities between the physical profile of this species and the species identified in this study may be because the plants (in both studies) were collected from regions with identical climates.

In contrast, the essential oil of $L$. gracilis was observed to be mainly composed of 1,8-cineole in this study, which does not correspond to the results of previous reports; the essential oil of the leaves of this species collected from São Felix de Balsas, Maranhão, was determined to contain over $70 \%$ of thymol [33]. Other studies have reported carvacrol to be the major component of this essential oil; however, the oil was extracted from samples collected in other states of the Brazilian northeastern region, such as Ceará and Pernambuco [34, 35]. Mendes et al. [36] identified thymol (24.1\%), p-cymene (15.9\%), and 1,8-cineole (4.8\%) to be the major chemical components of the essential oil of $L$. gracilis obtained from São Cristovão, Sergipe, in Brazil.

These results highlight the need for testing the composition of essential oils using analytical techniques. The biological properties of the plants are known to depend on their composition, independent of their products (essential oils, fixed oils, latex, resins, or extracts). Among the numerous plant-derived products, essential oils are considered to have the most variable composition because of external (soil, climate, and altitude) and internal (age, portion of the plant) factors $[37,38]$. As such, the study of the chemical composition of essential oils from aromatic plants is fundamental to the scientific understanding of plant-derived products and may lay the foundation for the development of humanoriented assets.

3.2. Larvicidal Activity. The essential oil obtained from $M$. erythroxylon was considered to be inactive since it did not kill mosquito larvae, even at the highest concentration studied $(1000 \mathrm{mg} / \mathrm{L})$; the remaining essential oils were considered to be effective ( $\mathrm{LC}_{50}$ between 230 and $292 \mathrm{mg} / \mathrm{L}$, after $24 \mathrm{~h}$ of exposure) (Table 3 ).

The highest concentration studied for the effective essential oils was $400 \mathrm{mg} / \mathrm{L}$. The larvae subjected to this concentration were agitated during the first $30 \mathrm{~min}$ of exposure; following this, the larvae showed slowed and abnormal 
TABLE 2: Main constituents of the essential oils (of plants obtained from the Brazilian Legal Amazon) tested against Aedes aegypti L. (Diptera: Culicidae) larvae.

\begin{tabular}{|c|c|c|c|c|c|c|}
\hline \multirow{2}{*}{ Compounds ${ }^{\mathrm{a}} /$ classes } & \multirow{2}{*}{$\mathrm{RI}^{\mathrm{b}}$} & \multicolumn{5}{|c|}{ Plant species/relative content ${ }^{\mathrm{c}}(\%)$} \\
\hline & & Epi & $\mathrm{Me}$ & $\mathrm{Pm}$ & Sc & $\mathrm{Lg}$ \\
\hline$\alpha$-Pinene & 931 & 3.54 & - & - & - & - \\
\hline Sabinene & 977 & - & - & - & - & 2.72 \\
\hline$\beta$-Pinene & 977 & 7.08 & - & - & - & 6.22 \\
\hline Myrcene & 989 & - & - & 1.32 & - & 2.2 \\
\hline$\alpha$-Phellandrene & 1003 & - & - & - & 12.8 & - \\
\hline$\alpha$-Terpinene & 1017 & - & - & - & - & 0.92 \\
\hline p-Cymene & 1024 & - & - & - & 1.5 & 1.35 \\
\hline Limonene & 1029 & 1.27 & - & - & 4.9 & - \\
\hline 1,8-Cineole & 1034 & - & - & 0.66 & - & 56.16 \\
\hline (E)- $\beta$-Ocimene & 1046 & 5.52 & - & - & - & - \\
\hline$\gamma$-Terpinene & 1059 & - & - & - & - & 3.55 \\
\hline$\alpha$-Terpinolene & 1085 & - & - & - & 0.41 & - \\
\hline Linalool & 1100 & - & - & 0.78 & - & - \\
\hline trans-Pinocarveol & 1140 & - & - & - & - & 3.42 \\
\hline$\delta$-Terpineol & 1167 & - & - & - & - & 1.02 \\
\hline Terpinen-4-ol & 1180 & - & - & - & - & 3.83 \\
\hline$\alpha$-Terpineol & 1186 & 0.43 & - & - & - & 12.09 \\
\hline Geraniol & 1256 & - & - & - & 0.49 & - \\
\hline (E)-Linalool oxide acetate & 1286 & - & - & - & 0.46 & - \\
\hline$\delta$-Elemene & 1335 & 3.49 & - & - & 4.9 & - \\
\hline$\alpha$-Copaene & 1378 & 1.5 & 1.85 & - & 0.38 & - \\
\hline$\beta$-Bourbonene & 1386 & 0.57 & - & - & - & - \\
\hline$\beta$-Elemene & 1390 & 4.79 & 2.41 & - & 3.29 & - \\
\hline$\alpha$-Gurjunene & 1412 & - & 0.52 & 0.43 & - & - \\
\hline (E)- $\beta$-Caryophyllene & 1419 & 16.46 & 10.55 & 26.05 & 3.17 & 1.12 \\
\hline$\beta$-Gurjunene & 1432 & - & 4.71 & - & 3.36 & - \\
\hline$\gamma$-Elemene & 1434 & 17.48 & 5.38 & - & - & - \\
\hline$\alpha$-Guaiene & 1438 & - & - & - & 1.94 & - \\
\hline Aromadendrene & 1440 & 2.29 & 1.06 & 1.4 & - & - \\
\hline Guaiadiene-6,9 & 1444 & - & - & - & 9.23 & - \\
\hline trans-Muurola-3,5-diene & 1450 & - & - & - & 1.47 & - \\
\hline$\alpha$-Humulene & 1455 & 2.18 & - & 23.92 & 0.69 & 1.49 \\
\hline allo-Aromadendrene & 1462 & - & 2.64 & - & - & - \\
\hline Bicyclogermacrene & 1470 & 8.11 & 13.26 & - & 5.11 & - \\
\hline$\gamma$-Muurolene & 1480 & 0.91 & - & 0.63 & - & - \\
\hline Germacrene D & 1482 & 5.64 & 26.79 & - & - & - \\
\hline$\gamma$-Patchoulene & 1484 & - & - & - & 28.63 & - \\
\hline$\beta$-Selinene & 1487 & 1.23 & - & 1.95 & 1.6 & - \\
\hline$\alpha$-Selinene & 1496 & - & - & 1.25 & - & - \\
\hline Viridiflorene & 1497 & 1.42 & - & - & - & - \\
\hline$\alpha$-Muurolene & 1501 & - & - & - & 3.76 & - \\
\hline$\delta$-Cadinene & 1523 & 2.95 & 9.63 & - & 0.72 & - \\
\hline Zonarene & 1526 & - & - & 3.53 & - & - \\
\hline$\alpha$-Cadinene & 1539 & - & 1.22 & - & - & - \\
\hline Selina-3,7(11)-diene & 1542 & - & - & 2.05 & 0.57 & - \\
\hline Germacrene B & 1558 & 1.99 & - & - & - & - \\
\hline Spathulenol & 1578 & 2.5 & 3.25 & - & 1.33 & - \\
\hline
\end{tabular}


TABLE 2: Continued.

\begin{tabular}{|c|c|c|c|c|c|c|}
\hline \multirow{2}{*}{ Compounds ${ }^{\mathrm{a}} /$ classes } & \multirow{2}{*}{$\mathrm{RI}^{\mathrm{b}}$} & \multicolumn{5}{|c|}{ Plant species/relative content ${ }^{\mathrm{c}}(\%)$} \\
\hline & & Epi & $\mathrm{Me}$ & $\mathrm{Pm}$ & Sc & $\operatorname{Lg}$ \\
\hline Caryophyllene oxide & 1581 & - & - & 10.09 & - & - \\
\hline Globulol & 1585 & - & 4.16 & - & - & - \\
\hline Viridiflorol & 1590 & 2.33 & - & 2.19 & 5.02 & - \\
\hline Humulene epoxide II & 1601 & - & - & 6.37 & - & - \\
\hline epi-Cubenol & 1626 & - & - & - & 2.14 & - \\
\hline Caryophylledienol II & 1631 & - & - & 5.66 & - & - \\
\hline epi- $\alpha$-Cadinol & 1639 & - & - & 2.73 & - & - \\
\hline$\tau$-Muurolol & 1640 & 0.81 & 2.26 & - & 0.36 & - \\
\hline$\alpha$-Cadinol & 1654 & 1.05 & 2.25 & 3.81 & 1.09 & - \\
\hline Monoterpene hydrocarbons & & 17.41 & - & 1.32 & 19.61 & 16.96 \\
\hline Oxygenated monoterpenes & & 0.43 & - & 1.44 & 0.95 & 81.07 \\
\hline Sesquiterpene hydrocarbons & & 71.01 & 80.02 & 61.21 & 68.87 & 2.61 \\
\hline Oxygenated sesquiterpenes & & 6.69 & 11.92 & 30.85 & 9.94 & - \\
\hline Total & & 95.54 & 91.94 & 94.82 & 99.37 & 99.64 \\
\hline
\end{tabular}

${ }^{\mathrm{a}}$ Compounds listed in order of elution on the DB-5ms column.

${ }^{\mathrm{b}}$ Retention indices (RIs) experimentally determined against $\mathrm{n}$-alkanes by using the DB-5ms column.

${ }^{\mathrm{C}}$ Content expressed as percentages obtained by integration of the GC peak area.

RI: retention index; Epi: Eugenia piauhiensis Vellaff.; Me: Myrcia erythroxylon O. Berg; Pm: Psidium myrsinites DC.; Sc: Siparuna camporum (Tul.) A. DC.; Lg: Lippia gracilis Schauer. Conditions of analysis: gas chromatograph associated with mass spectrometer THERMO DSQ II; chemical constituents identified by comparison of the mass spectra obtained with published spectra [21,22].

TABLE 3: Lethal concentrations for $50 \%$ of the test subjects (Aedes aegypti L.; $n=10)\left(\mathrm{LC}_{50}\right)$ of the essential oils obtained from plant species endemic to the Brazilian Legal Amazon after $24 \mathrm{~h}$ of exposure.

\begin{tabular}{lc}
\hline Plant species & LC $_{50}{ }^{\mathrm{a}}(\mathrm{mg} / \mathrm{L})$ \\
\hline Eugenia piauhiensis Vellaff. & $230(194-306)^{\mathrm{b}}$ \\
Myrcia erythroxylon O. Berg & $>1000$ \\
Psidium myrsinites DC. & $292(212-386)^{\mathrm{b}}$ \\
Siparuna camporum (Tul.) A. DC. & $251(207-312)^{\mathrm{b}}$ \\
Lippia gracilis Schauer & $282(259-306)^{\mathrm{b}}$ \\
\hline${ }^{\mathrm{a}} \mathrm{LC}_{50}$ was calculated by probit analysis using SPSS software version 13.0. \\
${ }^{\mathrm{b}}$ Confidence interval of 95\%; no dead larvae were observed in the negative \\
control, composed of 0.01\% DMSO solution; the positive control, $1 \mathrm{mg} / \mathrm{L}$ \\
temefos, exhibited 100\% larval mortality.
\end{tabular}

movements, including tremors and convulsions. The larvae were afflicted with paralysis and floated to the bottom of the containers prior to death. The mortality rate was observed to be directly proportional to the tested concentrations.

Aedes aegypti L. is an important vector of dengue and chikungunya fever, diseases that still cause high morbidity and mortality in several countries of the world [39]. The lack of effective vaccines and specific therapies for these diseases has prompted the search for new approaches to control mosquito population, notably because of the increase in mosquito resistance to conventional pesticides [40, 41]. The observation that essential oils could be used as effective natural insecticides $[42,43]$ has inspired a series of studies, which have confirmed the biological larvicidal potential of essential oils against $A$. aegypti larvae $[9,44]$.
This study tested the larvicidal potential of selected essential oils against $A$. aegypti. This study utilized the procedures proposed by the WHO [27], which establishes the protocols to be used for the study of efficacy; however, the recommendations did not define the larval stage, or the time of exposure for the assays. Therefore, these studies cannot be standardized, which has complicated the comparison of results between different interspecies and intraspecies studies.

Another important factor that is not usually discussed in scientific reports is the origin of the larvae used (fieldcollected or laboratory-reared). In general, the field-collected larvae are more resistant to pesticides compared to those reared under laboratory conditions, as the former are better adapted to adjust to environmental variations and express higher genetic variability $[45,46]$. The same compound $((R)-$ (-)-carvone) showed different larvicidal potential against larvae reared in the laboratory for more than 10 years and those collected in fields (known to have larval strains resistant to temefos) $[47,48]$.

Since the WHO has not established a standard criterion for determining the larvicidal activity of natural products, several authors have developed individual criteria to characterize the potency of mosquito larvicides developed from natural products $[44,49,50]$. Komalamisra et al. [51] considered products showing $\mathrm{LC}_{50} \leq 50 \mathrm{mg} / \mathrm{L}$ to be active, $50 \mathrm{mg} / \mathrm{L}<$ $\mathrm{LC}_{50} \leq 100 \mathrm{mg} / \mathrm{L}$ to be moderately active, $100 \mathrm{mg} / \mathrm{L}<\mathrm{LC}_{50} \leq$ $750 \mathrm{mg} / \mathrm{L}$ to be effective, and $\mathrm{LC}_{50}>750 \mathrm{mg} / \mathrm{L}$ to be inactive. Ravi Kiran et al. [52] considered compounds with LC $_{50}<$ $100 \mathrm{mg} / \mathrm{L}$ to exhibit a significant larvicidal effect. It should be stressed that these criteria must be directly correlated with 
the time of exposure and the origin of larvae, which are variables that can alter the $\mathrm{LC}_{50}$ values.

The results obtained in this study showed that four of the five plant species had promising effects, according to the criterion established by Komalamisra et al. [51], exhibiting $\mathrm{LC}_{50}$ between 230 and $292 \mathrm{mg} / \mathrm{L}$ after $24 \mathrm{~h}$ of exposure. These values were obtained for the essential oils extracted from $E$. piauhiensis, P. myrsinites, S. camporum, and L. gracilis.

The oil extracted from the leaves of $L$. gracilis has been previously researched. The studies conducted by Santiago et al. [53] and Silva et al. [54] showed lower LC $_{50}$ values than the ones observed in this work. However, the experimental conditions were considerably different, especially compared to those utilized by Silva et al. [54], who used laboratoryreared larvae. In addition, it must be emphasized that the chemical composition of these oils may vary; the previous study indicated that the oxygenated monoterpene, carvacrol, was the major component found in this species, while this study identified 1,8-cineole to be the major component.

The essential oils extracted from E. piauhiensis and $S$. camporum showed the most promising larvicidal potential, with lower LC $_{50}$ values. The essential oils of the Myrtaceae species were, in the past, believed to be active against $A$. aegypt $i$ larvae [7]. Essential oils from other species belonging to the genera Eugenia L. and Psidium L. are also considered to be active against $A$. aegypti larvae. These include Eugenia melanadenia Krug \& Urb., Psidium guajava L., and Psidium rotundatum Griseb. [55, 56].

The M. erythroxylon extract was the only essential oil considered inactive as a larvicide in this study. In contrast, the essential oil extracted from leaves of another species of the same genus, $M$. ovata Cambess., showed larvicidal activity [56]. This is one example highlighting that the results of such studies should not be correlated with the chemicaltaxonomic classification. This is especially true in the case of essential oils; the chemical-taxonomic approach is not always an adequate tool for the selection of plants to be researched.

\section{Conclusions}

The use of plant-derived products, such as essential oils, in the production of natural larvicidal insecticides, could be a promising tool to help reduce the spread of dengue and chikungunya fever. This is because these products are the natural sources of substances displaying insecticidal activity against mosquito (affecting the different stages of mosquito development). In addition, these products are biodegradable and express low toxicity towards nontarget organisms.

However, it is important to standardize the procedures used for the determination of larvicidal activity. To this effect, the WHO must establish specific procedures for the control or elimination of $A$. aegypti larvae.

The $A$. aegypti larvae were observed to be sensitive to four of the five essential oils tested in this study. In light of these results, we stress the importance of describing the chemical composition and biological properties of essential oils. This would help in the development of products with larvicidal activities from Amazonian plants. It should also be stressed that any product developed should be accompanied by a rational and sustainable production system, in order to protect the Amazonian biodiversity.

\section{Conflict of Interests}

The authors declare no conflict of interests.

\section{Acknowledgments}

The authors are grateful to CNPq/BIONORTE program, CAPES, and FAPEMA for financial grants through the concession of scholarships and financial support.

\section{References}

[1] C. A. Almeida, D. M. Valeriano, M. I. S. Escada, and C. D. Rennó, "Estimation of secondary vegetation area in the Brazilian Legal Amazon," Acta Amazonica, vol. 40, no. 2, pp. 289-302, 2010.

[2] H. A. M. Xaud, F. D. S. R. V. Martins, and J. R. Dos Santos, "Tropical forest degradation by mega-fires in the northern Brazilian Amazon," Forest Ecology and Management, vol. 294, pp. 97-106, 2013.

[3] Portal da Legislação, "Decreto s/no de 12 de dezembro de 2005. Cria o Parque Nacional da Chapada das Mesas, nos Municípios de Carolina, Riachão e Estreito, no Estado do Maranhão, e dá outras providências," Legislação Federal DOU DE 13/12/2005 P2, Portal da Legislação, Brasília, Brazil, 2005.

[4] R. M. May, "Why worry about how many species and their loss?" PLoS Biology, vol. 9, no. 8, Article ID 1001130, 2011.

[5] F. D. S. S. Frickmann and A. G. Vasconcellos, "Research and patent of phytotherapeutic and phytocosmetic products in the Brazilian Amazon," Journal of Technology Management and Innovation, vol. 6, no. 4, pp. 136-150, 2011.

[6] R. Vila, A. I. Santana, R. Pérez-Rosés et al., "Composition and biological activity of the essential oil from leaves of Plinia cerrocampanensis, a new source of $\alpha$-bisabolol," Bioresource Technology, vol. 101, no. 7, pp. 2510-2514, 2010.

[7] H.-M. Park, J. Kim, K.-S. Chang et al., "Larvicidal activity of myrtaceae essential oils and their components against Aedes aegypti, acute toxicity on Daphnia magna, and aqueous residue," Journal of Medical Entomology, vol. 48, no. 2, pp. 405-410, 2011.

[8] M. Govindarajan, R. Sivakumar, M. Rajeswari, and K. Yogalakshmi, "Chemical composition and larvicidal activity of essential oil from Mentha spicata (Linn.) against three mosquito species," Parasitology Research, vol. 110, no. 5, pp. 2023-2032, 2012.

[9] C. N. Dias and D. F. C. Moraes, "Essential oils and their compounds as Aedes aegypti L. (Diptera: Culicidae) larvicides: review," Parasitology Research, vol. 113, pp. 565-592, 2014.

[10] Brazil Ministry of Health, Guia de Vigilância Epidemiológica, Ministério da Saúde, Brasilia, Brazil, 7th edition, 2010.

[11] Brazil Ministry of Health, Chikungunya Fever: Clinical Management, Ministério da Saúde, Brasilia, Brazil, 1st edition, 2015.

[12] WHO, Handbook for Integrated Vector Management, World Health Organization, Geneva, Switzerland, 2012.

[13] T. E. Morrison, "Reemergence of chikungunya virus," Journal of Virology, vol. 88, no. 20, pp. 11644-11647, 2014.

[14] Ministry of Health (Brazil), Monitoring of Dengue Cases to the Epidemiological Week (SE) and 41 Chikunguya Fever Until (IF) 42 2014, Ministério da Saúde, Brasília, Brazil, 1st edition, 2014. 
[15] R. Galler and M. C. Bonaldo, "Dengue vaccines: closer but not there yet," Memorias do Instituto Oswaldo Cruz, vol. 106, no. 8, pp. 905-906, 2011.

[16] D. J. Gubler, "Dengue, urbanization and globalization: the unholy trinity of the 21st century," Tropical Medicine and Health, vol. 39, no. 4, pp. S3-S11, 2011.

[17] I. A. Braga and D. Valle, "Aedes aegypti: inseticidas, mecanismos de ação e resistência," Epidemiol. e Serviços Saúde, vol. 16, pp. 279-293, 2007.

[18] WHO, Pesticides and Their Application: For the Control of Vectors and Pests of Public Health Importance, World Health Organization, Geneva, Switzerland, 6th edition, 2006.

[19] M. L. G. Macoris, Mecanismos de resistência de Aedes aegypti L. (Diptera: Culicidae) a inseticidas, Universidade Estadual Paulista, Botucatu, Brazil, 2011.

[20] J. Vontas, E. Kioulos, N. Pavlidi, E. Morou, A. della Torre, and H. Ranson, "Insecticide resistance in the major dengue vectors Aedes albopictus and Aedes aegypti," Pesticide Biochemistry and Physiology, vol. 104, no. 2, pp. 126-131, 2012.

[21] J. G. S. Maia, M. G. B. Zoghbi, A. S. Santos, and L. S. Ramos, "Óleos Essenciais da Amazônia: Inventário da Flora Aromática," in Tópicos Especiais em Tecnologia de Produtos Naturais, L. J. G. Faria and C. M. L. Costa, Eds., pp. 127-146, UFPA/NUMA/POEMA, Belém, Brazil, 1st edition, 1998.

[22] NIST, Mass Spectral Library (NIST/EPA/NIH), National Institute of Standards and Technology, Gaithersburg, Md, USA, 2005.

[23] J. K. R. da Silva, L. C. Pinto, R. M. R. Burbano et al., "Essential oils of Amazon Piper species and their cytotoxic, antifungal, antioxidant and anti-cholinesterase activities," Industrial Crops and Products, vol. 58, pp. 55-60, 2014.

[24] R. P. Adams, Identification of Essential Oil Components by Gas Chromatography/Mass Spectrometry, Allured, Carol Stream, Ill, USA, 4th edition, 2007.

[25] A. E. Lenhart, M. Walle, H. Cedillo, and A. Kroeger, "Building a better ovitrap for detecting Aedes aegypti oviposition," Acta Tropica, vol. 96, no. 1, pp. 56-59, 2005.

[26] R. A. G. B. Consoli and R. L. Oliveira, Principais mosquitos de importância sanitária no Brasil, Fiocruz, Rio de Janeiro, Brasil, 1994.

[27] WHO, Guidelines for Laboratory and Field Testing of Mosquito Larvicides, WHO/CDS/WHOPES/GCDPP, Geneva, Switzerland, 2005.

[28] N. S. Sangwan, A. H. A. Farooqi, F. Shabih, and R. S. Sangwan, "Regulation of essential oil production in plants," Plant Growth Regulation, vol. 34, no. 1, pp. 3-21, 2001.

[29] L. Gobbo-Neto and N. P. Lopes, "Plantas medicinais: fatores de influência no conteúdo de metabólitos secundários," Química Nova, vol. 30, no. 2, pp. 374-381, 2007.

[30] D. P. Pavarini, S. P. Pavarini, M. Niehues, and N. P. Lopes, "Exogenous influences on plant secondary metabolite levels," Animal Feed Science and Technology, vol. 176, no. 1-4, pp. 5-16, 2012.

[31] K. A. D. F. Rodrigues, C. N. Dias, F. M. M. Do Amaral et al., "Molluscicidal and larvicidal activities and essential oil composition of Cymbopogon winterianus," Pharmaceutical Biology, vol. 51, no. 10, pp. 1293-1297, 2013.

[32] J. G. S. Maia, L. M. M. Carreira, and E. H. A. Andrade, "Óleos essenciais de Mirtáceas do cerrado do Maranhão," in Anais da 33a Reunião Anual da Sociedade Brasileira de Química, p. 1, 2010.
[33] C. S. Franco, A. F. Ribeiro, N. C. C. Carvalho et al., "Composition and antioxidant and antifungal activities of the essential oil from Lippia gracilis Schauer,' African Journal of Biotechnology, vol. 13, no. 30, pp. 3107-3113, 2014.

[34] C. C. De Albuquerque, T. R. Camara, R. D. L. R. Mariano, L. Willadino, C. Marcelino Jr., and C. Ulisses, "Antimicrobial action of the essential oil of Lippia gracilis schauer," Brazilian Archives of Biology and Technology, vol. 49, no. 4, pp. 527-535, 2006.

[35] R. M. Neto, F. J. A. Matos, V. S. Andrade et al., "The essential oil from Lippia gracilis Schauer, Verbenaceae, in diabetic rats," Brazilian Journal of Pharmacognosy, vol. 20, no. 2, pp. 261-266, 2010.

[36] S. S. Mendes, R. R. Bomfim, H. C. R. Jesus et al., "Evaluation of the analgesic and anti-inflammatory effects of the essential oil of Lippia gracilis leaves," Journal of Ethnopharmacology, vol. 129, no. 3, pp. 391-397, 2010.

[37] E. M. A. Feitosa, Â. M. C. Arriaga, G. M. P. Santiago et al., "Chemical composition and larvicidal activity of Rollinia leptopetala (Annonaceae)," Journal of the Brazilian Chemical Society, vol. 20, no. 2, pp. 375-378, 2009.

[38] P. C. S. Barbosa, R. S. Medeiros, P. T. B. Sampaio, B. G. Vieira, L. S. M. Wiedemann, and V. F. Veiga Jr., "Influence of abiotic factors on the chemical composition of copaiba oil (Copaifera multijuga hayne): soil composition, seasonality and diameter at breast height," Journal of the Brazilian Chemical Society, vol. 23, no. 10, pp. 1823-1833, 2012.

[39] P. Tattevin, "Dengue, chikungunya: two emerging arboviruses," Journal des Anti-Infectieux, vol. 14, no. 2, pp. 78-88, 2012.

[40] K. A. Polson, W. G. Brogdon, S. C. Rawlins, and D. D. Chadee, "Characterization of insecticide resistance in Trinidadian strains of Aedes aegypti mosquitoes," Acta Tropica, vol. 117, no. 1, pp. 31-38, 2011.

[41] E. A. D. Santos, C. M. D. Carvalho, A. L. S. Costa, A. S. Conceição, F. D. B. P. Moura, and A. E. G. Santana, "Bioactivity evaluation of plant extracts used in indigenous medicine against the snail, Biomphalaria glabrata, and the larvae of Aedes aegypti," Evidence-Based Complementary and Alternative Medicine, vol. 2012, Article ID 846583, 9 pages, 2012.

[42] F. Bakkali, S. Averbeck, D. Averbeck, and M. Idaomar, "Biological effects of essential oils-a review," Food and Chemical Toxicology, vol. 46, no. 2, pp. 446-475, 2008.

[43] J. D. Hare, "Ecological role of volatiles produced by plants in response to damage by herbivorous insects," Annual Review of Entomology, vol. 56, pp. 161-180, 2011.

[44] F. Massebo, M. Tadesse, T. Bekele, M. Balkew, and T. GebreMichael, "Evaluation on larvicidal effects of essential oils of some local plants against Anopheles arabiensis Patton and Aedes aegypti Linnaeus (Diptera, Culicidae) in Ethiopia," African Journal of Biotechnology, vol. 8, no. 17, pp. 4183-4188, 2009.

[45] S. George and S. Vincent, "Comparative efficacy of Annona squamosa Linn. and Pongamia glabra Vent. to Azadirachta indica A. Juss against mosquitoes," Journal of Vector Borne Diseases, vol. 42, no. 4, pp. 159-163, 2005.

[46] L. Sun, H. Dong, C. Guo et al., "Larvicidal activity of extracts of Ginkgo biloba exocarp for three different strains of Culex pipiens pallens," Journal of Medical Entomology, vol. 43, no. 2, pp. 258261, 2006.

[47] N. K. Simas, E. D. C. Lima, S. D. R. Conceição, R. M. Kuster, A. M. de Oliveira Filho, and C. L. S. Lage, "Natural products for dengue transmission control-Larvicidal activity of Myroxylon 
balsamum (red oil) and of terpenoids and phenylpropanoids," Quimica Nova, vol. 27, no. 1, pp. 46-49, 2004.

[48] S. R. L. Santos, M. A. Melo, A. V. Cardoso, R. L. C. Santos, D. P. de Sousa, and S. C. H. Cavalcanti, "Structure-activity relationships of larvicidal monoterpenes and derivatives against Aedes aegypti Linn," Chemosphere, vol. 84, no. 1, pp. 150-153, 2011.

[49] J. M. Chantraine, D. Laurent, C. Ballivian, G. Saavedra, R. Ibañez, and L. A. Vilaseca, "Insecticidal activity of essential oils on Aedes aegypti larvae," Phytotherapy Research, vol. 12, no. 5, pp. 350-354, 1998.

[50] L. A. M. Magalhães, M. Da Paz Lima, M. O. M. Marques, R. Facanali, A. C. Da Silva Pinto, and W. P. Tadei, "Chemical composition and larvicidal activity against Aedes aegypti larvae of essential oils from four Guarea species," Molecules, vol. 15, no. 8, pp. 5734-5741, 2010.

[51] N. Komalamisra, Y. Trongtokit, Y. Rongsriyam, and C. Apiwathnasorn, "Screening for larvicidal activity in some Thai plants against four mosquito vector species," Southeast Asian Journal of Tropical Medicine and Public Health, vol. 36, no. 6, pp. 14121422, 2005.

[52] S. Ravi Kiran, K. Bhavani, P. Sita Devi, B. R. Rajeswara Rao, and K. Janardhan Reddy, "Composition and larvicidal activity of leaves and stem essential oils of Chloroxylon swietenia DC against Aedes aegypti and Anopheles stephensi," Bioresource Technology, vol. 97, no. 18, pp. 2481-2484, 2006.

[53] G. M. P. Santiago, T. L. G. Lemos, O. D. L. Pessoa et al., "Larvicidal activity against Aedes aegypti L. (Diptera: Culicidae) of essential oils of Lippia species from Brazil," Natural Product Communications, vol. 1, no. 7, pp. 573-576, 2006.

[54] W. J. Silva, G. A. A. Dória, R. T. Maia et al., "Effects of essential oils on Aedes aegypti larvae: alternatives to environmentally safe insecticides," Bioresource Technology, vol. 99, no. 8, pp. 32513255, 2008.

[55] L. Aguilera, A. Navarro, J. E. Tacoronte, M. Leyva, and M. C. Marquetti, "Efecto letal de myrtaceas cubanas sobre Aedes aegypti (Díptera: Culicidae)," Revista Cubana de Medicina Tropical, vol. 55, no. 2, pp. 100-104, 2003.

[56] M. A. A. Lima, F. F. M. de Oliveira, G. A. Gomes et al., "Evaluation of larvicidal activity of the essential oils of plants species from brazil against Aedes aegypti (Diptera: Culicidae)," African Journal of Biotechnology, vol. 10, no. 55, pp. 11716-11720, 2011. 


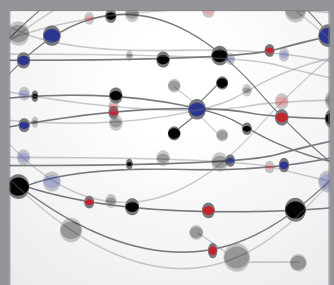

The Scientific World Journal
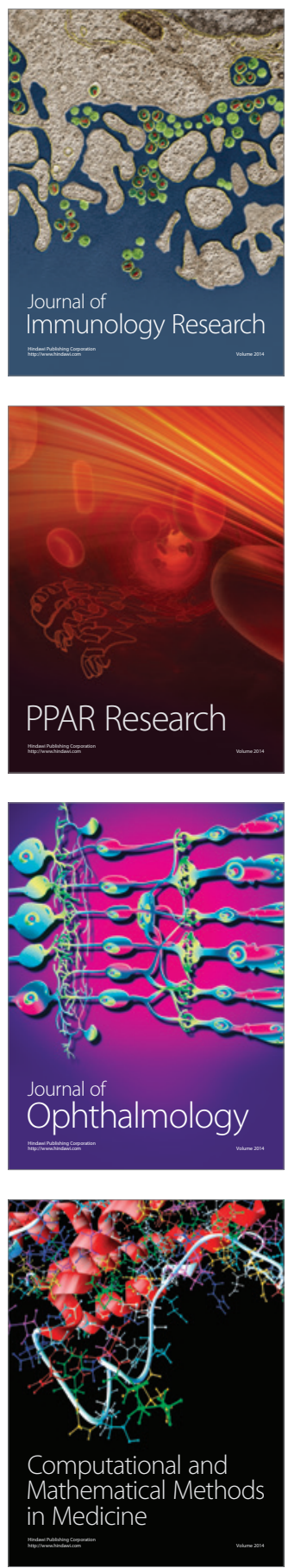

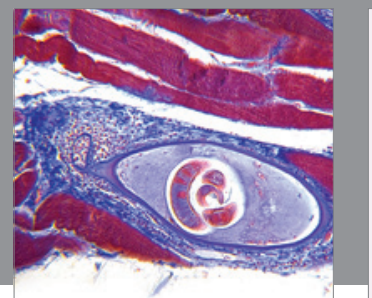

Gastroenterology

Research and Practice
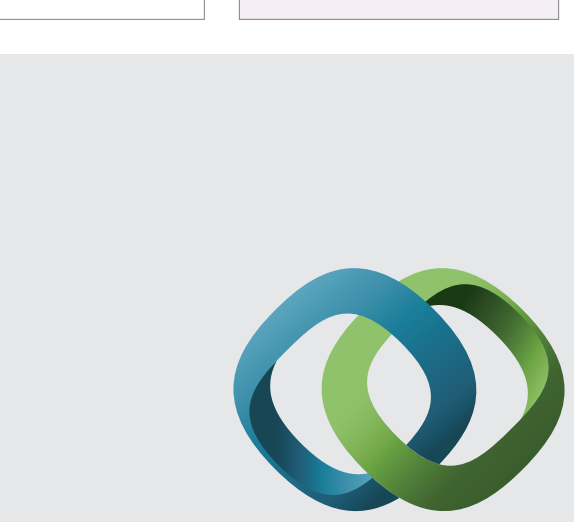

\section{Hindawi}

Submit your manuscripts at

http://www.hindawi.com
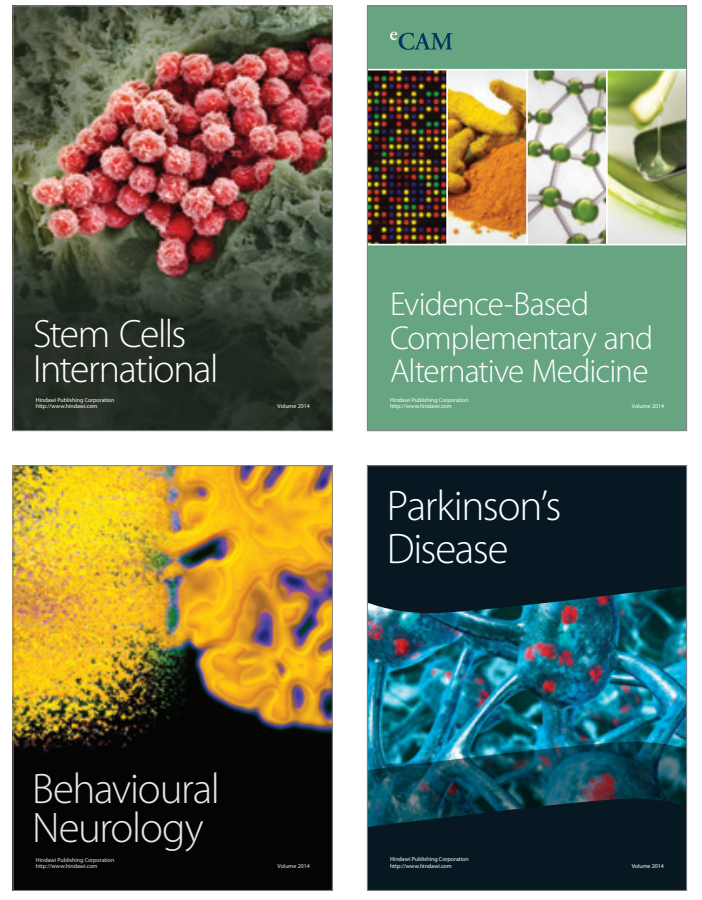
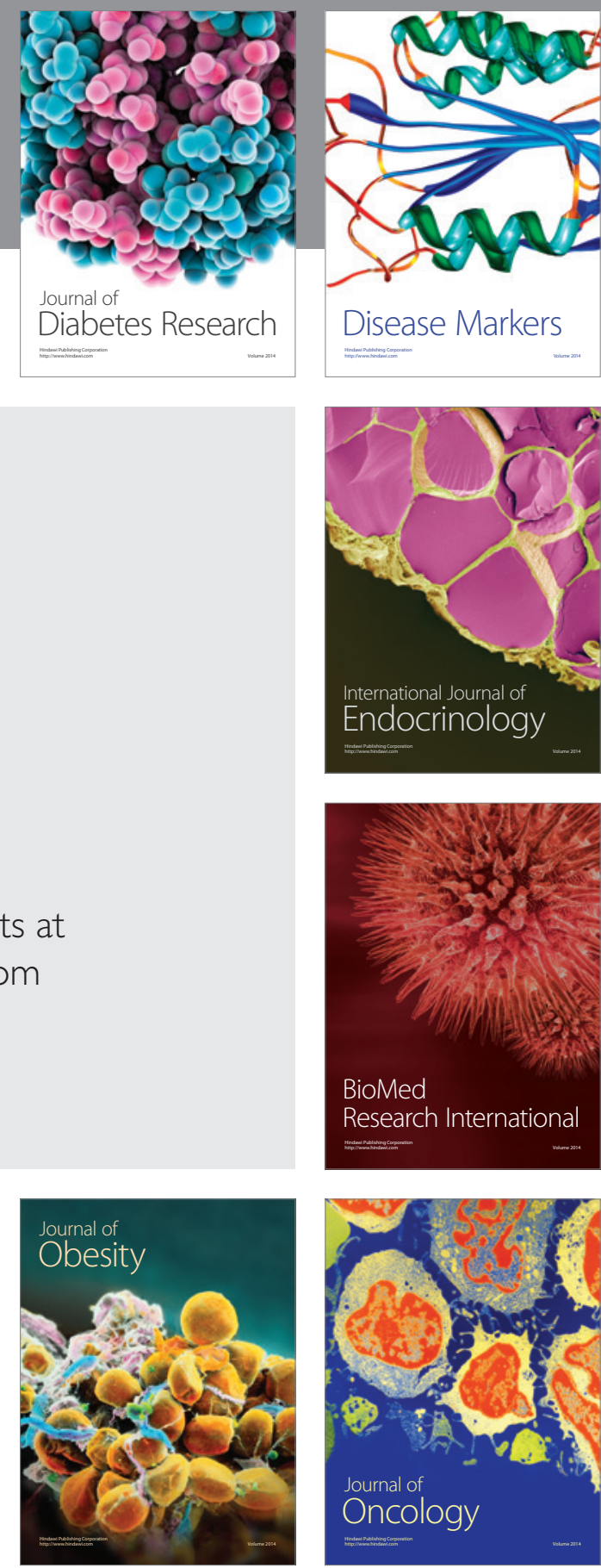

Disease Markers
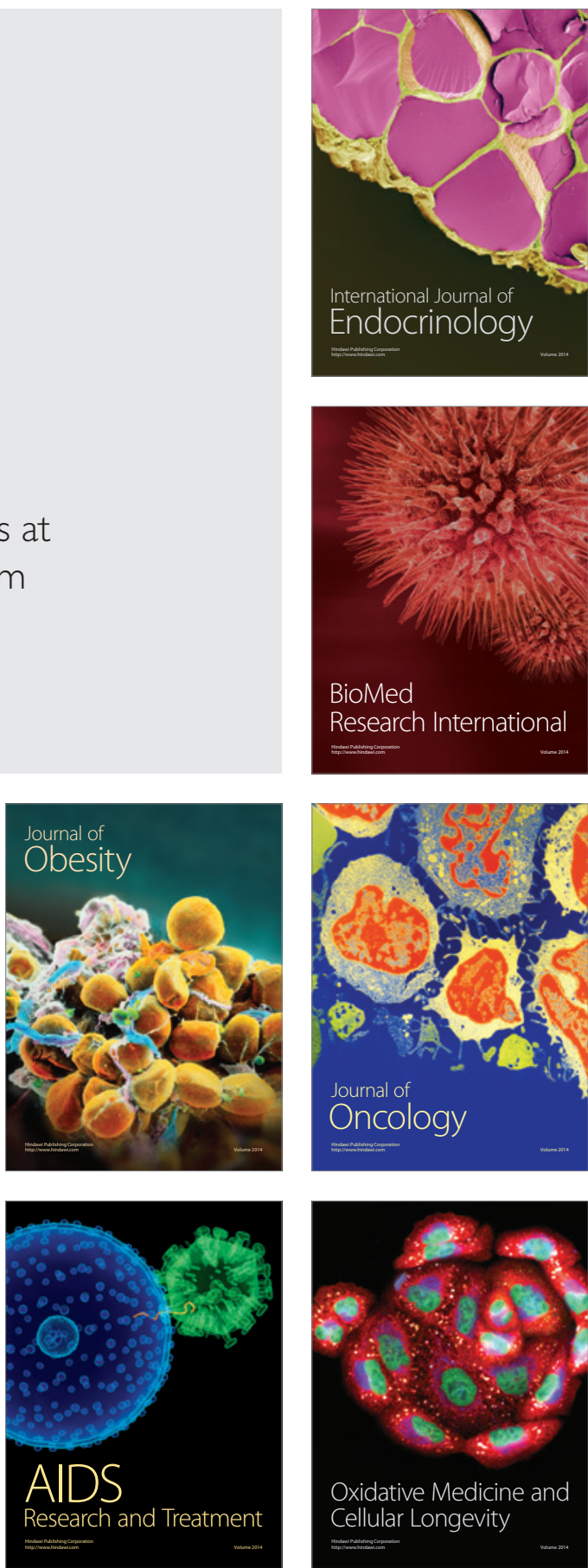